\title{
Age and growth of the tilapia, Oreochromis niloticus (Perciformes: Cichlidae) from a tropical shallow lake in Mexico
}

\author{
José Luis Gómez-Márquez ${ }^{1}$, Bertha Peña-Mendoza ${ }^{1}$, Isaías H. Salgado-Ugarte ${ }^{1}$ \& José Luis \\ Arredondo-Figueroa ${ }^{2}$ \\ 1. Laboratorio de Limnología, F.E.S. Zaragoza, U.N.A.M. Av. 5 de Mayo y Fuerte de Loreto, Col. Ejército de Oriente, \\ Iztapalapa, C.P. 09230, México D.F., México. Fax: 5773 6336; lgomez@servidor.unam.mx \\ 2. Planta Experimental de Producción Acuícola, Departamento de Hidrobiología, CBS, Universidad Autónoma \\ Metropolitana Iztapalapa, Av. San Rafael Atlixco 186, Col. Vicentina, Iztapalapa 09340, México D.F., México. Tel: \\ 58044740, Fax: 58044738; afj1@xanum.uam.mx
}

Received 26-IX-2006. Corrected 22-VI-2007. Accepted 31-X-2007.

\begin{abstract}
Age and growth of Nile tilapia (Oreochromis niloticus) were determined using 1039 specimens collected in a tropical shallow lake of Mexico, from January to December 1993. Standard length of females ranged from 9.0 to $16.5 \mathrm{~cm}$ and males from 8.9 to $14.8 \mathrm{~cm}$. The standard length-weight relationships for all individuals was $\mathrm{BW}=0.1207 \mathrm{SL}^{2.469}$. The age data, derived from opercular bone readings, were used to estimate the growth parameters of the von Bertalanffy equation: $\mathrm{L}_{\infty}=17.88 \mathrm{~cm}, \mathrm{~K}=0.3409, \mathrm{t}_{\mathrm{o}}=-1.543$, and $\mathrm{W}_{\infty}=149.21 \mathrm{~g}$. The oldest male and female were 2.5 years old. The sex ratio (female:male) was of $1: 1\left(\chi^{2}=0.02, \mathrm{p}>0.05\right)$. Rev. Biol. Trop. 56 (2): 875-884. Epub 2008 June 30.
\end{abstract}

Key words: Oreochromis niloticus, age, growth, opercular bone, sex ratio, Mexico.

Tilapias are members of the Cichlidae family, native to the streams and lakes of Africa and Madagascar. They have been introduced in natural waters into a large number of tropical and sub-tropical countries in over 100 countries in the Central and South America Tropical Zone (Fryer and Iles 1972, Morales 1991). The tilapia in Mexico is one of the three most important freshwater fisheries; this species represents a fifth of the world production (Sugunan 1997). The first fish introduced to Mexico (Temascal, Oaxaca) in 1964 from Auburn University, Alabama, USA were Tilapia rendalli, Oreochromis mossambicus and $O$. aureus, (Arredondo-Figueroa and GuzmánArroyo 1986), and became widely distributed throughout natural and artificial water reservoirs in tropical and temperate regions of the country (Morales 1991).

In 1976, Nile tilapia Oreochromis niloticus (Linnaeus, 1757) was introduced to Mexico from Panama (Arredondo-Figueroa and Tejeda-Salinas 1989). In 1990, juveniles of this species were released into different tropical shallow lakes between them, Coatetelco Lake in Morelos State.

In Mexico, the annual production of tilapias was 74734 metric ton in 2000 (Anonymous 2001). This value represents about $5.3 \%$ of total national production from fish caught in inland waters and from fish farming. Nowadays, this species is found in almost all the inland waters of the Morelos State, where the commercial catch was of 597 metric ton in 2000 and, contributes to the entire landed catch from most of the Mexico waters. Studies on the Lake Coatetelco are very important; because they are the basis to determine the rate at which a rational exploitation should be realized (Oduleye 1982).

Annual growth rings are therefore not formed in most tropical fishes as in temperate 
fishes, and consequently the age of the fish species cannot easily be determined. It is therefore, desirable to find other methods in determining the age of tropical fishes. Attempts to resolve this problem have been few. Garrod (1959) with Tilapia esculenta and Payne and Collinson (1983) with Sarotherodon niloticus, correlated the spawning with the formation of annual growth rings in scales. Fagade (1974) in Tilapia melanotheron (Ruppell) and Jiménez-Badillo (2006) in O. aureus, found that complete growth rings on the opercular bones were formed.

Knowledge on the age of this important species is an essential prerequisite to a more detailed study on its biology and to manage its fisheries. Although this species represent an important food and economical source in Coatetelco lake, to date not many studies on its ecology and population dynamics have been carried out in this tropical shallow lake, in relation with tilapia's age and growth, except the realized by Gómez-Márquez (1998).

The objective of this study was to obtain data on age and growth rate of Nile tilapia $O$. niloticus, by means of opercular bone readings in Lake Coatetelco, a tropical shallow lake.

\section{MATERIAL AND METHODS}

Study site: Lake Coatetelco (Lat: $18^{\circ} 45^{\prime}$ $\mathrm{N}$; Long: $99^{\circ} 20^{\prime} \mathrm{W}$ ) is located at an altitude of $1100 \mathrm{~m}$ in Morelos State (Anonymous 1981, Anonymous 1998). It has a surface area of approximately 120 ha, a mean depth of 0.49 $\mathrm{m}$ and a maximum depth of $1.5 \mathrm{~m}$ (GómezMárquez 2002). Samples from the commercial catch were taken form various sites of Lake Coatetelco from January to December 1993. Fish were caught by static gill-net with mesh size $5.08 \mathrm{~cm}$. A total of 1039 fish were analyzed. After capture, all fish were measured for total length (TL) and standard length (SL) to the nearest $0.1 \mathrm{~cm}$ and weighed (body weight, BW) to the nearest $0.1 \mathrm{~g}$. The sex was determined by examination of internal organs. Opercular bones were removed from both sides of the body, cleaned in 5\% ammonium hydroxide solution for $24 \mathrm{~h}$, washed in distilled water and stored in polyethylene bags until their examination. Rings were interpreted and counted using a binocular microscope. Each opercular bone was read twice by two different readers, without knowledge of the length of the specimen. Samples considered unreadable, or if discrepancies could not be resolved were excluded from the analysis. The maximum posterior radius of each opercular bone (OR) was measured using an ocular micrometer. This measure (OR) was defined as the maximum distance from the focus to the distal edge of the bone. The distance from the focus to each ring was measured along this axis (Fig. 1). SL-OR regressions were tested for differences in slopes between sexes using Student's t test (Steel and Torrie 1981). Linear, exponential and power models were fitted to determine what equations best describe the relationship between body length and opercular bone radius. The length frequency distribution analysis was employed through the Powell-Wetherall procedure (Sparre and Venema 1997) using the FiSAT program (Gayanilo et al. 1994) to estimate the growth parameter $\mathrm{L}_{\infty}$.

The validation of age and the periodicity of the ring formation were verified through marginal growth examination (Yamaguchi et al. 1990). The perimeters of 619 opercular bones sampled at monthly intervals were examined. August was excluded from analysis due to have not specimens. The composition of the outer

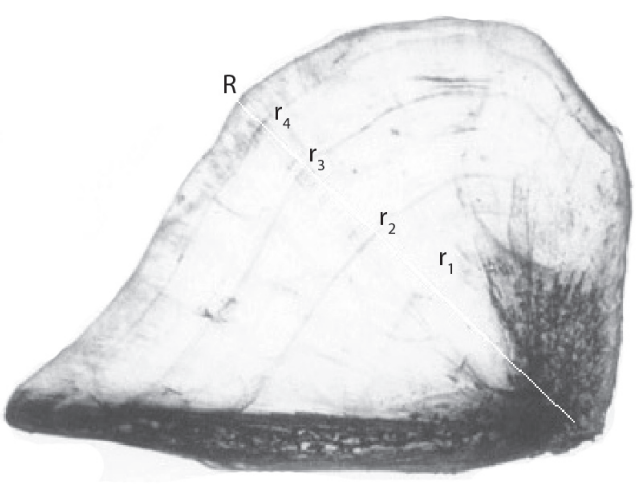

Fig. 1. Opercular bone from a specimen of two years. The measurement axis also is showed. 
margin was noted and expressed as a percentage of the monthly sample.

The mean lengths at age derived from opercular bone readings by sex and for both sexes combined, together with their standard deviations (S.D.), were calculated. The non-linear regression program available in StataCorp (1997) with the von Bertalanffy function specification implemented by Salgado-Ugarte et al. (2000) was used to estimate the growth parameters $\mathrm{L}_{\infty}, \mathrm{k}$ and $\mathrm{t}_{\mathrm{o}}$. This procedure uses the Gauss-Newton search algorithm to determine the estimates that minimize the residuals sum of squares.

The length-weight relationship was described by the equation $\mathrm{BW}=\mathrm{aSL}^{\mathrm{b}}$, where BW is the body weight, SL the standard length, $b$ the growth exponent or length-weight factor, and $a$ is a constant. Student's t-test was used to accept (or reject) the hypothesis of isometric growth (Ricker 1975, Pualy 1984). Length growth and weight-length relationship data were used to obtain the expected weight for each age. Taylor's (1960) equation was used to calculate age limit or longevity $\left(95 \%\right.$ of $\left.\mathrm{L}_{\infty}\right)$.

The catalogue number of voucher specimens is IBUNAM-P 8832.

\section{RESULTS}

A total of 1039 fish were measured, 538 were females (51.8\%) and 501 males (48.2\%). Standard length of males ranged from 8.9 to $14.8 \mathrm{~cm}$ (females from 9.0 to $16.5 \mathrm{~cm}$ ) (Fig. 2) and their weight from 25.7 to $106.5 \mathrm{~g}$ (females from 25.8 to $165 \mathrm{~g}$ ). The TL mean for females and males did not differ significantly (Student's $t=1.649, \mathrm{p}>0.05$ ), and relationship between standard length and total length was statistically significant:

$\mathrm{SL}=-0.229+0.794 \mathrm{TL},\left(\mathrm{r}^{2}=0.9462, \mathrm{p}<0.05\right)$

The total weight-standard length relationship were separately evaluated for all individuals, and grouped by sex (females and males), and the slopes of BW-SL regressions did not differ significantly between sexes (Student's $t=-0.077, \mathrm{p}>0.05)$. Therefore, the equation for all individuals is given below:

$$
\mathrm{BW}=0.1207 \mathrm{SL}^{2.469},\left(\mathrm{r}^{2}=0.8114, \mathrm{p}<0.05\right)
$$

Weight increased allometrically with size (Fig. 3); since $b$ value was significantly less than 3 (Student's $t=5.84, \mathrm{p}<0.05$ ), this relationship indicated a negative allometric growth.

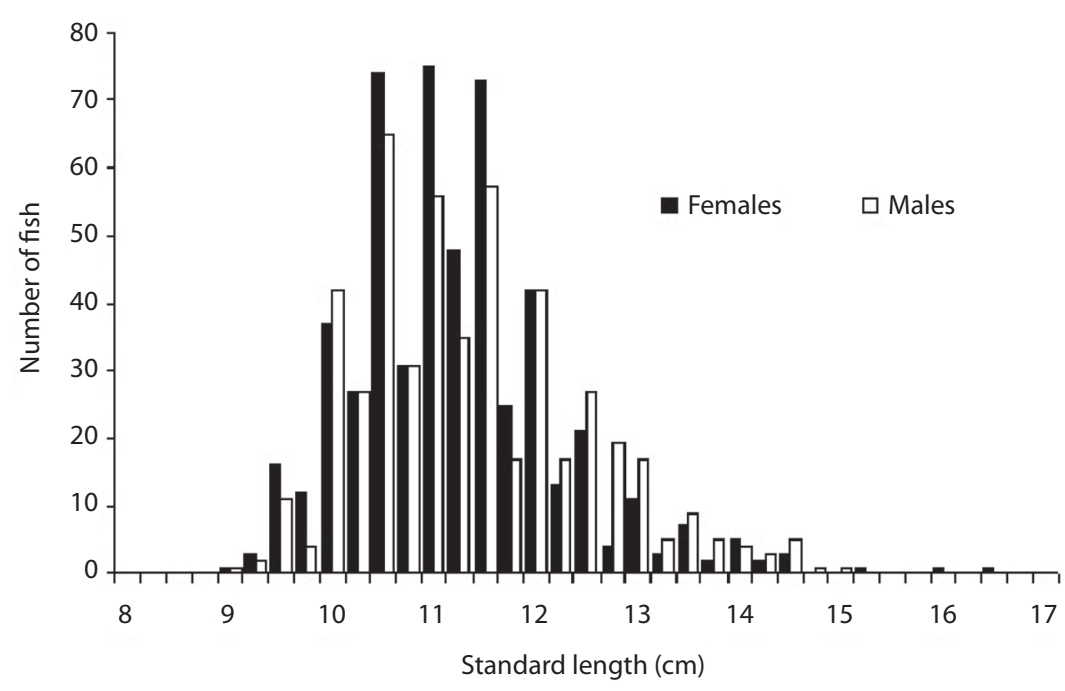

Fig. 2. Length-frequency distribution of $O$. niloticus at Coatetelco lake. 


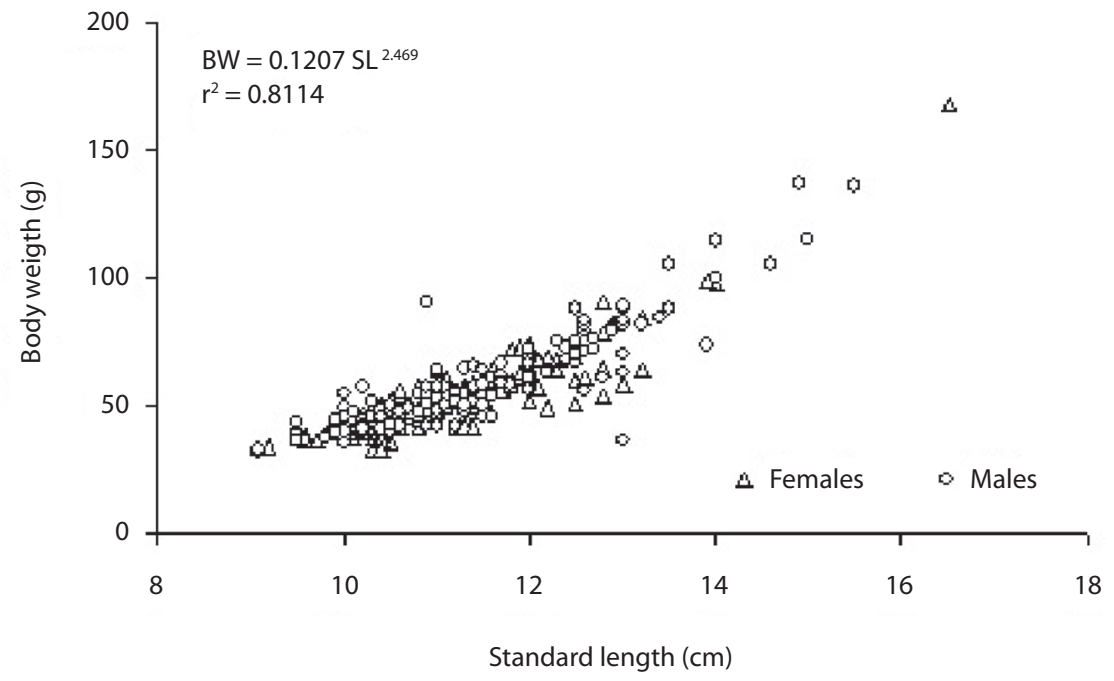

Fig. 3. Total weight -standard length relationship of $O$. niloticus, sexes combined.

A total of 1039 opercular bones were collected. Only fifty-nine percent of the opercular bones (300 females and 319 males) were used for age and growth study. The slopes of SL-OR regressions did not differ significantly between sexes (Student's $t=-0.1253, \mathrm{p}>0.05$ ).

Standard length (SL)-left opercular bone radius (OR) relationships of tilapia with combined sexes were described best by a linear function $\mathrm{SL}=7.21+3.12 \mathrm{OR}$, with $\mathrm{r}$-value of $0.7374(\mathrm{p}<0.05)$. The opercular bone radius measured vertically (Fig. 1) was better correlated with fish standard length than when measured diagonally. Opercular bone readings suggested five age groups. The results of mean length obtained from opercular bone readings for combined sexes are provided in Table 1 . Length at age observed by hard part readings were displayed using box plots (Fig. 4).

The marginal increment index showed a minimum value in July; on the other hand from December to January, the opercular bone border analysis shows that most fishes caught during this period had completed a ring close to the edge. Therefore, age for each growth mark was interpreted as an age of six months and, the maximum age registered in this study for this species was two and a half years. An estimated asymptotic length value $\left(L_{\infty}\right)$ of $21.03 \mathrm{~cm}$ was obtained by using the Powell-Wetherall procedure (length frequency distribution analysis). The estimated von Bertalanffy growth constants by non linear regression for combined sexes are: $\mathrm{L}_{\infty}=17.88 \mathrm{~cm} ; \mathrm{W}_{\infty}=149.21 \mathrm{~g}, \mathrm{k}=0.3409$ and $\mathrm{t}_{0}=-1.543$ (Adj. R-squared $=0.9996$ ). The value of $L_{\infty}$ is higher that the maximum observed standard length (Fig. 5).

Taylor's (1960) equation indicates that age limit or longevity for the tilapia is 36 months. A total of 1039 tilapias were dissected to determine sex (501 males and 538 females). The sex

TABLE 1

Mean standard length $(\mathrm{cm}) \pm$ S.D. at age for O. niloticus

$\begin{array}{ccc}\begin{array}{c}\text { Age } \\ \text { (years) }\end{array} & \begin{array}{c}\text { Mean length of fish } \\ (\mathrm{cm}) \pm \text { s.d. }\end{array} & \text { Number of fish } \\ 0.5 & 8.89 \pm 0.62 & 214 \\ 1.0 & 10.61 \pm 0.79 & 90 \\ 1.5 & 11.41 \pm 0.87 & 230 \\ 2.0 & 12.46 \pm 1.22 & 55 \\ 2.5 & 13.46 \pm 1.57 & 30\end{array}$




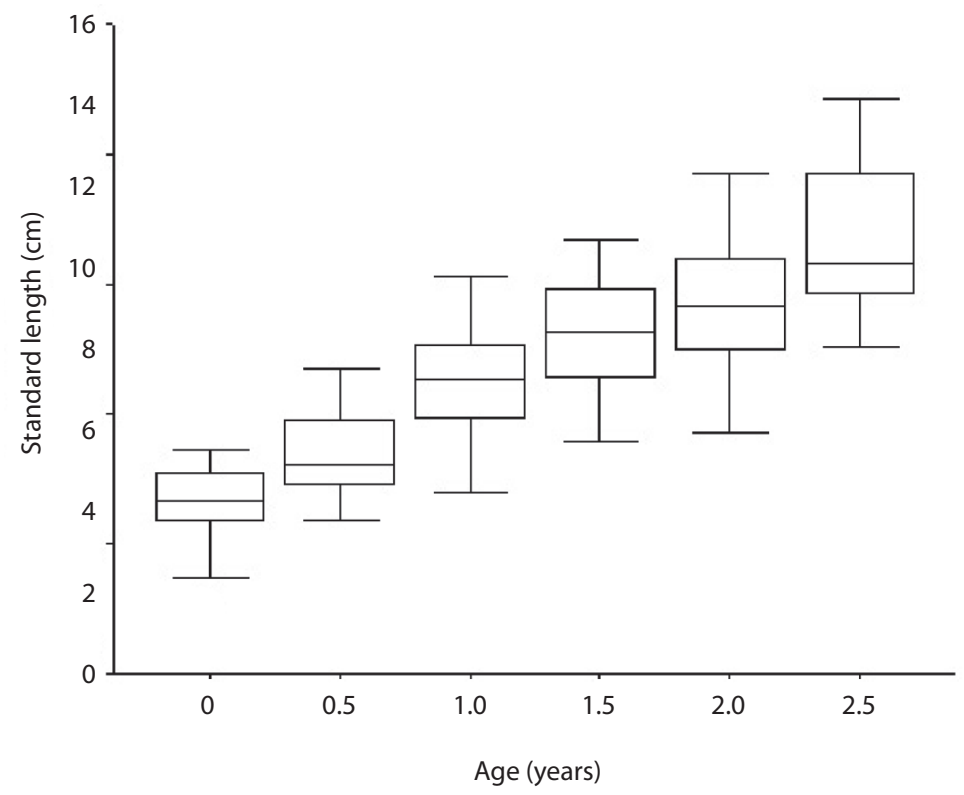

Fig. 4. Median length at age estimated by opercular bones for $O$. niloticus.

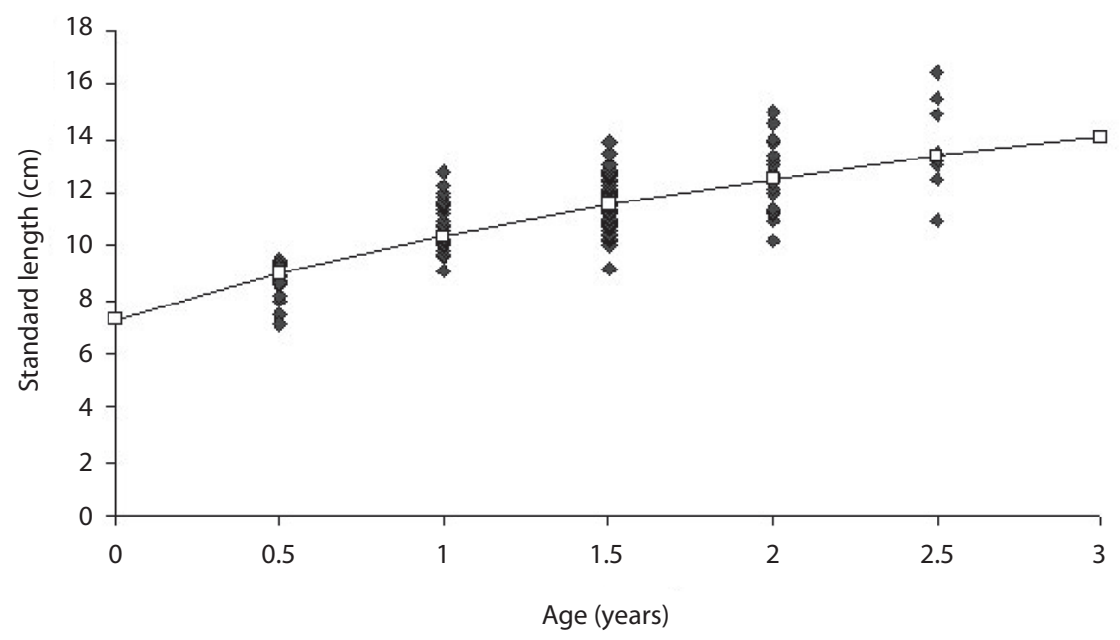

Fig. 5. von Bertalanffy growth curve in length of $O$. niloticus from Coatetelco lake. 
ratio of the catch as a whole was not significantly different from a $1: 1$ sex ratio $\left(\chi^{2}=0.02\right.$, $\mathrm{p}>0.05)$. The proportion of males was higher from January to March.

\section{DISCUSSION}

In the present study, the SL for tilapia ranged from 9.0 to $16.5 \mathrm{~cm}$; the male's range was smaller than that from females. This difference could be attributed to variation in the ontogenetic development stages, as well as condition and maturity differences between sexes. Respect to total weight-standard length relationship we suppose that negative allometry was caused by the capture of mainly young individuals as the length-frequency distribution of $O$. niloticus shows.

The formation of growth marks in the opercular bones of Nile tilapia was observed in July (warm month), which corresponds with a minimum value of marginal growth. This event may be attributed to high temperatures $\left(32{ }^{\circ} \mathrm{C}\right)$ and rainy days prevailing in the lake during this season, besides the conductivity on the lake water and an increase in its silt content will also influence the physiology of the fish in one way or another.

However, the percentage of fish caught during December-January and July had a complete ring close to the edge, and therefore the growth rings found on the opercular bones were probably due to growth interruption caused by the gonad maturation and the spawning activity (Gómez-Márquez et al. 2003). This is because $O$. niloticus is a mouth brooder and it is possible that in the females, this breeding habit would prevent feeding and thus lead to growth mark formation.

Blake and Blake (1978) cited that at least two check marks were found on the opercular bones of Labeo senegalensis in Lake Kainji, one of these occurring during June-July, and another during January. Jellvman (1980) mentioned that the age of Perca fluviatilis was calculated from annual bands in the opercular bones and the growth was seasonal (annual). Blake and Blake (1981) reported that in Chanos chanos and Pomadasys macracanthus in a coastal lagoon from Mexico, two check marks were found on the opercular bones. Peterson et al. (1999) found that in Cycleptus meridionalis opercular bones indicated that one annulus was formed during September-October, at the beginning of the reproductive season.

Yamaguchi et al. (1990) found that the formation of rings in scales of $O$. niloticus in High Dam Lake, Egypt, occurred every January when they used the minimum value of marginal increment.

In relation with ring formation, Fagade (1974) working with Tilapia malanotheron from Lagos Lagoon found that the complete growth rings on the opercular bone are formed probably by the spawning activity during the height of the rainy season and incomplete growth rings formed during the dry season. Jiménez-Badillo (2006) cited for O. aureus that "the rings on scales and opercular bones were due to periods of fast or slow growth imposed by reproductive energetic demands".

Blake and Blake (1978) mentioned that the growth rings in Labeo senegalensis are formed as a result of minimum water temperature, and for onset of the rains associated with a limited food supply. Garrod (1959) has shown that in the mouth breeding Tilapia esculenta caught in Lake Victoria, the growth rings are formed in the scales as a result of spawning. The same pattern was reported by Alejo et al. (1989) for O. mossambicus, Guzmán (1994) for O. aureus and Gómez-Márquez (1998) for O. niloticus from Mexico. It is possible that the frequency of spawning could be influenced by the abundance and seasonal availability of food and by other environmental factors at different localities (Babiker and Ibrahim 1979, Oduleye 1982).

Payne and Collinson (1983) mentioned that food availability and spawning, affect the ring formation on $O$. niloticus scales. Also, Garrod (1959) and Fagade (1973) suggest that growth marks on hard structures in tropical fish are results of factors such as reproductive activity, feeding intensity, salinity and water level.

On the other hand, Louberis and Panfili (1992) from readings of different calcified 
structures (scales, otoliths, dorsal ray and opercular bone) concluded that scales with their growth marks, were better than the opercular bone for aging Prochilodus nigricans. Moreover, Göçer and Ekingen (2005) mentioned that dorsal fin rays were the best bony structure for the age determination of Liza ramada followed by scales, vertebrae, otoliths and opercular bones and, the reliability decreased in the same order. Also Quinton et al. (2007) found that the age estimates from common carp scales, vertebrae, and opercula exhibited lower precision than did pectoral fin rays.

With reference to growth parameters, Booth and Merron (1996) found for Oreochromis macrochir values of body length of $21.5 \mathrm{~cm}$. A similar value was obtained by using the Powell-Wetherall procedure in this study. Gómez-Márquez (1998) for O. niloticus reported values of $29.19 \mathrm{~cm}$ standard length. This value is very different to that obtained in this study. It is possible that the observed difference is likely due to non representative sampling, that the growth marks were often unclear and inconsistent, they had the lowest confidence scores, the longer reading times, and only $55 \%$ within-reader agreement.

Studies in several other species of Oreochromis (Guerra and Peña 1985, Alejo et al. 1989) from tropical shallow temporary ponds in Morelos State had been carried out and similar results in standard body length were obtained in comparison with this study using opercular bones. The rapid linear growth observed during the first year of life may represent an adaptation evolved to reduce its vulnerability to the environment. This also is reported by Jiménez-Badillo (2006) for O. aureus.

Flores (1994) found that $O$. niloticus in ponds at Mexico City, attains $20.7 \mathrm{~cm}$ of asymptotic standard length $\left(L_{\infty}\right)$ with a growth coefficient of 0.2038 . Although this asymptotic value is larger than the one obtained in this study, the mean values used by this author were similar to those used to estimate the growth parameters of the von Bertalanffy growth function (VBGF).
On the order hand, age limit or longevity for the tilapia was 36 months. This value reflects the impact that fishing has on tilapia individual growth and consequently on the population age structure, that do not surpass the two year and a half age. Fishing is forcing a precocious maturity by leaving the individuals that reproduce at earlier ages compensating in this way the high fishing mortality, with the consequent selection of less favourable characters of growth.

In the present study the sex ratio (1:1) for $O$. niloticus indicates that males and females are statistically equal in number; this is possibly caused by the incidence of fish pairs near to the nest area where females take care of their broods. Fawole and Arawomo (2000) mentioned that for every female there is a male specimen in Sarotherodon galilaeus. Babiker and Ibrahim (1979) reported similar results for O. niloticus. Sex ratio was different in each one of the samples and this behavior could be favorable to the fishery, because this can serve as a regulatory mechanism for the sex ratio. Nikolsky (1963) cited that the sex ratio varies considerably from species to species, but in the majority of cases it is close to one, and may vary form year to year in the same population.

However, this proportion evidently reduces the number of recruits obtained for population recuperation, because all tilapia introductions have come from a reduced number of progenitors and the renovation of the stock is null, so there are a dwarfish tendency. According to Gómez-Márquez (1998, 2002), an increase in the size mesh of gill nets up to $8 \mathrm{~cm}$ could contribute to protect the reproductive potential of the stock, aid to recovery its population and to achieve a better yield per recruit. An appropriate regulation in tilapia exploitation in Coatetelco lake is necessary.

Unfortunately sufficient clarity over total opercular bones surface was not observed in this study, because only the fifty-nine percent of the opercular bones (300 females and 319 males) were used. Sipe and Chittenden Jr. (2001) obtained similar result for Paralichthys dentatus. 
Our data show that at least two growth bands by year are formed, and this together with the high correlation found between standard length and opercular bone radius, demonstrate the validity of using opercular bones for estimating the age and past growth history of tilapia. Jiménez-Badillo (2006) mentioned that the extraction, preparation and reading of opercular bones in comparison with scales were relatively easier. Moreover, opercular bones represented a more appropriate bone structure to evaluate tilapia growth.

This aquatic system has a high nutritional potential from the physical and chemical point of view, and it is considered as eutrophic (Granados 1990, Gómez-Márquez 1998); therefore, we are convinced that specimens with a larger average total body length could be obtained in Coatetelco lake.

\section{ACKNOWLEDGMENTS}

We thank the help of Mercedes Garduño Paredes and Juan Avelar Esquivel for collecting and processing specimens. This work was supported by Facultad de Estudios Superiores Zaragoza, UNAM and Secretaría de Desarrollo Rural del Estado de Morelos, México.

\section{RESUMEN}

Se determinó la edad y el crecimiento de la tilapia del Nilo (Oreochromis niloticus) utilizando 1039 organismos que fueron recolectados de Enero a Diciembre de 1993 en un lago somero tropical de México. La talla para las hembras osciló entre 9.0 y $16.5 \mathrm{~cm}$ longitud patrón y para los machos entre 8.9 y $14.8 \mathrm{~cm}$. La relación peso totallongitud patrón para toda la población fue $\mathrm{P}=0.1207 \mathrm{~L}^{2.469}$. Los datos de edad obtenidos a través de los anillos del hueso opercular se utilizaron para estimar los parámetros de crecimiento del modelo de von Bertalanffy: $\mathrm{L}_{\infty}=17.88$ $\mathrm{cm}, \mathrm{K}=0.3409, \mathrm{t}_{\mathrm{o}}=-1.543$ y $\mathrm{P}_{\infty}=149.21 \mathrm{~g}$. La edad máxima obtenida para hembras y machos fue de 2.5 año. La proporción sexual (hembra:macho) para la especie fue de 1:1 $\left(\chi^{2}=0.02, p>0.05\right)$.

Palabras claves: Oreochromis niloticus, edad, crecimiento, hueso opercular, proporción sexual, México.

\section{REFERENCES}

Alejo, P.M.C., M.E.M. Laguna \& P.T. Ramírez. 1989. Estudio de algunos aspectos Biológicos de Oreochromis mossambicus (Osteichthyes: Cichlidae) en la Laguna "El Rodeo", Estado de Morelos. Tesis de Licenciatura, Escuela Nacional de Estudios Profesionales Zaragoza, UNAM, México D.F., México.

Anonymous. 1981. Síntesis Geográfica de Morelos. Coordinación General de los Servicios Nacionales de Estadística, Geografía e Informática, México D.F., México.

Anonymous. 1998. Anuario Estadístico del Estado de Morelos. Instituto Nacional de Estadística, Geografía e Informática, Aguascalientes, México.

Anonymous. 2001. Anuario Estadístico de Pesca (2000). Dirección General de Informática, Estadística y Documentación. Secretaría de Pesca, México D.F., México.

Arredondo-Figueroa, J.L. \& M. Guzmán-Arroyo. 1986. Actual situación taxonómica de las especies de la Tribu Tilapiini (Pisces: Cichlidae) introducidas en México. An. Inst. Biól. UNAM 56, Ser. Zool. 2: 555-572.

Arredondo-Figueroa, J.L. \& M. Tejeda-Salinas. 1989. El hueso faríngeo, una estructura útil para la identificación de especies de la tribu Tilapiini (Pisces: Cichlidae) introducidas en México. An. Inst. Cienc. del Mar y Limnol. UNAM 16: 59-68.

Babiker, M.M. \& H. Ibrahim. 1979. Studies on the biology of reproduction in the cichlid Tilapia nilotica (L): Gonadal maturation and fecundity. J. Fish Biol. 14: 437-447.

Blake, C. \& B.F. Blake. 1978. The use of opercular bones in the study of age and growth in Labeo senegalensis from Lake Kainji, Nigeria. J. Fish Biol. 13: 287-295.

Blake, C. \& B.F. Blake. 1981. Age determination in six species of fish in a Mexican Pacific coastal lagoon. J. Fish Biol. 18: 471-478.

Booth, A.J. \& G.S. Merron. 1996. The age and growth of the greenhead tilapia Oreochromis macrochir (Pisces:Cichlidae) from the Okavango Delta, Botswana. Hydrobiologia 321: 29-34.

Fagade, S.O. 1974. Age determination in Tilapia melanotheron (Ruppell) in the Lagos Lagoon, Lagos, Nigeria: with a discussion on the environmental and 
physiological basis of growth markings in the tropics: 71-77. In T.B. Bagenal (ed.). The Ageing of Fish. Unwin, Old Woking, Surrey, England.

Fawole, O.O. \& G.A.O. Arawomo. 2000. Fecundity of Sarotherodon galilaeus (Pisces: Cichlidae) in the Opa reservoir, Ile-Ife, Nigeria. Rev. Biol. Trop. 48: 201-204.

Flores, M.O. 1994. Crecimiento de Oreochromis niloticus en estanques con diferente fertilización, en un clima templado. Tesis de Licenciatura, Facultad de Estudios Superiores Zaragoza, UNAM, México D.F., México.

Fryer, G. \& T.D. Iles. 1972. The Cichlid Fishes of the Great Lakes of Africa: Their Biology and Evolution. Oliver \& Boyd, Edinburgh. Scotland.

Gayanilo, F.C. Jr., P. Sparre \& D. Pauly. 1994. The FAOICLARM Stock Assessment Tools (FISAT) User's Guide. FAO. Computerized Information Series (Fisheries). No. 7. FAO, Roma, Italy.

Garrod, D.J. 1959. The growth of Tilapia esculenta Graham in Lake Victoria. Hydrobiologia 12: 268-298.

Göçer, M. \& G. Ekingen. 2005. Comparisons of various bony structures for the age determination of Liza ramada (Risso, 1826) population from the Mersin Bay. J. Fish. Aquat. Sci. 22: 211-213.

Gómez-Márquez, J.L. 1998. Age and growth of Oreochromis niloticus (Perciformes: Cichlidae) in Mexico. Rev. Biol. Trop. 46: 929-936.

Gómez-Márquez, J.L. 2002. Estudio limnológico-pesquero del lago de Coatetelco, Morelos, México. Tesis de Doctorado en Ciencias (Biología), Facultad de Ciencias, UNAM, México D.F., México.

Gómez-Márquez, J.L., B. Peña-Mendoza, I.H. Salgado-Ugarte \& M. Guzmán-Arroyo. 2003. Reproductive aspects of Oreochromis nilotiucs (Perciformes:Cichlidae) at Coatetelco lake, Morelos, Mexico. Rev. Biol. Trop. 51: 221-228.

Granados, R.J.G. 1990. El comportamiento del zooplancton en tres ambientes acuáticos epicontinentales del estado de Morelos, México. Tesis de Maestría en Ciencias (Biología), Facultad de Ciencias, UNAM, México D.F., México.

Guerra, H.E.A. \& M.B. Peña. 1985. Estudio del crecimiento de Oreochromis hornorum (Trewavas, 1980) en relación a las condiciones limnológicas del embalse permanente de Michapa, Edo. de Morelos.
Tesis de Licenciatura, Escuela Nacional de Estudios Profesionales Zaragoza, UNAM, México D.F., México.

Guzmán, U.A. 1994. Parámetros biológicos de tilapia (Oreochromis aureus Steindachner, 1864) de la presa Adolfo López Mateos "El Infiernillo", MichoacánGuerrero, México. Tesis de Licenciatura, Facultad de Ciencias, UNAM, México D.F., México.

Jellyman, D.J. 1980. Age, growth, and reproduction of perch, Perca fluviatilis L. in Lake Pounui. New Zeal. J. Mar. Freshw. Res. 14: 391-400.

Jiménez-Badillo, L. 2006. Age-growth models for tilapia Oreochromis aureus (Perciformes, Cichlidae) of the Infiernillo reservoir, Mexico and reproductive behaviour. Rev. Biol. Trop. 54: 577-588.

Louberis, G. \& J. Panfili. 1992. Age determination of Prochilodus nigricans (Teleostei, Prochilodidae) in Beni (Bolivia): setting of a procedure and application. Aquat. Living Resour. 5: 41-56

Morales, D.A. 1991. La tilapia en México. A.G.T., México D.F., México.

Nikolsky, D.V. 1963. The Ecology of Fishes. Academic, London.

Oduleye, S.O. 1982. Growth and growth regulation in the Cichlids. Aquaculture 27: 301-306.

Pauly, D. 1984. Fish population dynamics in tropical waters: A manual for use with programmable calculators. International Center for Living Aquatic Resources Management, Studies and Reviews 8, Manila, Philippines.

Payne, A. \& R. Collinson. 1983. A comparison of the biological characteristics of Sarotherodon niloticus (L.) with those of $S$. aureus (Steindachner) and other tilapia of the delta and lower Nile. Aquaculture 30: 335-351.

Peterson, M.S., C.L. Nicholson, J.D. Snyder \& L.G. Fulling. 1999. Growth, spawning, preparedness, and diet of Cycleptus meridionalis (Catostomidae). Trans. Am. Fish. Soc. 128: 900-908.

Quinton, E.P., R.E. Kris \& D.W. Willis. 2007. Precision of five structures for estimating age of common carp. North Am. J. Fish. Manag. 27:103-105,

Ricker, E.W. 1975. Computation and interpretation of biological statistics of fish populations. Bull. Fish. Res. Board. Can. (191): 145-157. 
Salgado-Ugarte, I.H., J. Martínez-Ramírez, J.L. GómezMárquez \& B. Peña-Mendoza. 2000. Some programs for growth estimation in fisheries biology. Stata Tech. Bull. 53: 35-47.

Sipe, M.A. \& M.E. Chittenden Jr. 2001. A comparison of calcified structures for aging summer flounder, Paralichthys dentatus. Fish. Bull. 99: 628-640.

Sparre, P. \& S.C. Venema. 1997. Introducción a la evaluación de recursos pesqueros tropicales. Parte I. Manual. FAO, Documento Técnico de Pesca, No. 306.1 Rev. 2., Chile.

Statacorp. 1997. Stata Statistical Software: Release 5.0. University Drive East, College Station, Texas, USA.
Steel, D.G.R. \& J.H. Torrie. 1981. Principles and Procedures of Statistics. A biometrical approach. McGraw-Hill, Nueva York, USA.

Sugunan, V.V. 1997. Fisheries management of small water bodies in seven countries in Africa, Asia and Latin America. FAO Fish. Circ. No. 933, FAO, Rome.

Taylor, C.C. 1960. Temperature, growth and mortality. The Pacific Cockle. J. du Conseil 26: 117-124.

Yamaguchi, Y., N. Hirayama, A. Koike \& H.A. Adam. 1990. Age determination and growth of Oreochromis niloticus and Sarotherodon galilaeus in High Dam Lake, Egypt Nippon Suisan Gakkaishi 56: 437-443 